See discussions, stats, and author profiles for this publication at: https://www.researchgate.net/publication/282875300

\title{
Peri-ovulatory endocrine regulation of the prostanoid pathways in the bovine uterus at early dioestrus
}

Article in Reproduction Fertility and Development · October 2015

DOI: $10.1071 /$ RD15269

\section{CITATION}

1

9 authors, including:

Milena L Oliveira

University of São Paulo

13 PUBLICATIONS 116 CITATIONS

SEE PROFILE

Veerle Van Hoeck

University of Antwerp

56 PUBLICATIONS 590 CITATIONS

SEE PROFILE
READS

157

7. Fuilherme Pugliesi

92 PUBLICATIONS 443 CITATIONS

SEE PROFILE

Fernando Silveira Mesquita

Universidade Federal do Pampa - Unipampa

59 PUBLICATIONS 336 CITATIONS

SEE PROFILE

Some of the authors of this publication are also working on these related projects:

Project NADPH oxidase-derived ROS role in growth factor signaling of uterine smooth muscle cells View project

Project Targeting Renal Microvascular Oxidative Stress in Cardiovascular \& Metabolic Disease View project 


\title{
Peri-ovulatory endocrine regulation of the prostanoid pathways in the bovine uterus at early dioestrus
}

\author{
Milena Lopes Oliveira ${ }^{\mathrm{A}}$, Fabio Luiz D'Alexandri ${ }^{\mathrm{A}}{ }^{\prime}$ Guilherme Pugliesi ${ }^{\mathrm{A}}$, \\ Veerle Van Hoeck ${ }^{\mathrm{A}}$, Fernando Silveira Mesquita ${ }^{\mathrm{B}}$, Claudia M. B. Membrive ${ }^{\mathrm{C}}$, \\ João Alberto Negrão ${ }^{\mathrm{D}}$, Craig E. Wheelock ${ }^{\mathrm{E}}$ and Mario Binelli ${ }^{\mathrm{A}, \mathrm{F}}$ \\ A Department of Animal Reproduction, School of Veterinary Medicine and Animal Science, \\ University of São Paulo - Avenida Duque de Caxias Norte, 225, 13630-000, Pirassununga, \\ SP, Brazil. \\ ${ }^{B}$ Universidade Federal do Pampa, School of Veterinary Medicine - BR472, Km592, 97508-000, \\ Uruguaiana, RS, Brazil. \\ CUniversidade Estadual Paulista 'Julio de Mesquita Filho' - Rodovia Comandante João Ribeiro de \\ Barros, Km65, 17900-000, Dracena, SP, Brazil. \\ ${ }^{D}$ College of Animal Science and Food Engineering, University of São Paulo - Avenida Duque de \\ Caxias Norte, 225, 13630-000, Pirassununga, SP, Brazil. \\ E Department of Medical Biochemistry and Biophysics, Division of Physiological Chemistry II, \\ Karolinska Institutet - SE-171 77 Stockholm, Sweden. \\ FCorresponding author. Email: binelli@usp.br
}

\begin{abstract}
We hypothesised that different endocrine profiles associated with pre-ovulatory follicle (POF) size would impact on uterine prostanoid pathways and thereby modulate the histotroph composition. Beef cows ( $n=15$ per group) were hormonally manipulated to have small (SF-SCL group) or large (LF-LCL group) pre-ovulatory follicles (POF) and corpora lutea (CL). Seven days after induction of ovulation, animals were slaughtered and uterine tissues and flushings were collected for quantification of prostanoids. The POF and CL size and the circulating progesterone concentrations at Day 7 were greater $(P<0.05)$ in the LF-LCL cows than in the SF-SCL group, as expected. The abundance of 5 out of 19 genes involved in prostanoid regulation was different between groups. Transcript abundance of prostaglandin F2 $\alpha$, E2 and 2 synthases was upregulated $(P<0.05)$ and phospholipase A2 was downregulated $(P<0.05)$ in endometrium of the LF-LCL group. No difference $(P>0.1)$ in prostanoid concentrations in the endometrium or in uterine flushings was detected between groups. However, prostaglandin F2 $\alpha$ and E2 concentrations in the uterine flushings were positively correlated with the abundance of transcripts for prostaglandin endoperoxide synthase $2(0.779$ and 0.865 , respectively; $P<0.002$ ). We conclude that endometrial gene expression related to prostanoid synthesis is modulated by the periovulatory endocrine profile associated with POF size, but at early dioestrus differences in transcript abundance were not reflected in changes in prostanoid concentrations in the uterine tissue and fluid.
\end{abstract}

Additional keywords: endometrium, oestrogen, physiology, prostaglandins.

Received 2 December 2014, accepted 16 August 2015, published online 14 October 2015

\section{Introduction}

A significant proportion of bovine females fail to become pregnant after insemination (Diskin et al. 2012; Pohler et al. 2012) and this has a negative economic impact on beef cattle operations. This high proportion of non-pregnant animals is mainly caused by early embryo loss (Diskin and Sreenan 1980; Diskin and Morris 2008). Therefore, necessary improvements in the reproductive efficiency depend on a greater understanding of the endocrine, cellular and molecular mechanisms involved in reproductive events during early dioestrus. The oviductal and uterine environments play a relevant role during the establishment and maintenance of pregnancy (Bauersachs et al. 2003; El-Sayed et al. 2006; Ulbrich et al. 2013). Indeed, previous studies determined that specific transcriptomic profiles at early dioestrus are necessary for adequate uterine receptivity (Forde et al. 2009; Mansouri-Attia et al. 2009; Walker et al. 2012; Beltman et al. 2014; Binelli et al. 2015; Mesquita et al. 2015). It is known that the timing and magnitude of oestradiol (E2) exposure during pro-oestrus and oestrus, followed by progesterone $(\mathrm{P} 4)$ at dioestrus, modulate gene expression in the endometrium and histotroph composition and function (Forde et al. 2009; Bridges et al. 2012; Ramos et al. 2015). In this 
context, Mesquita et al. (2014) also showed that the size of the pre-ovulatory follicle (POF) alters the peri-ovulatory endocrine milieu (i.e. the concentrations of E2 in pro-oestrus and $\mathrm{P} 4$ in dioestrus) and acts on the uterus to alter endometrial gene expression.

It is proposed that the uterine environment and receptivity might be modulated in response to peri-ovulatory endocrine changes. Several molecules and associated pathways have been proposed as key factors to determine uterine receptivity and the endocrine regulation of these pathways has been studied in detail by our group (Ramos et al. 2014, 2015; Araújo et al. 2015; França et al. 2015) and others (Bauersachs et al. 2006). However, the search continues for regulatory signals that might be involved in the critical processes of maternal receptivity in order to understand and subsequently tackle the possible causes for high rates of early embryonic death in beef cattle. In this context, reports have focussed on unravelling the complex role of the endometrial eicosanoid lipid mediators in the control of a range of reproductive processes (Weems et al. 2006). Prostanoids are well-described eicosanoids, which exert pivotal roles in regulation of reproductive processes such as ovulation, implantation, luteolysis and parturition in mammals (Lim et al. 1997; Wiltbank and Ottobre 2003). However, prostaglandin (PG) synthesis pathways are also important and active before maternal recognition of pregnancy in ruminants.

Previous studies have shown that bovine embryos at morula and blastocyst stages were susceptible to elevated prostaglandin F $2 \alpha$ (PGF2 $\alpha$ ) concentrations in the uterine lumen, which could negatively influence embryo viability and pregnancy rates (Schrick et al. 1993; Buford et al. 1996; Seals et al. 1998; Hockett et al. 2004). Regarding prostaglandin E2 (PGE2), the expression of its main synthase (prostaglandin E synthase (PTGES)) was downregulated in the endometrium of heifers with a retarded embryo at Day 7 after oestrus (Beltman et al. 2010), indicating that lack of PGE2 embryotrophic stimulus (Arosh et al. 2004; Ulbrich et al. 2009) could have contributed to the decreased fertility in these beef heifers. In addition, PGE2 is known to stimulate embryo implantation, luteal function and to modulate the uterine immune response and embryo development mainly by exerting anti-inflammatory effects (Arosh et al. 2004; Cong et al. 2006; Mosher et al. 2012; Vilella et al. 2013). Prostaglandin I2 (PGI2) improves the developmental competence of embryos, as the supplementation of in vitro culture medium with a PGI2 analogue improved embryonic quality by increasing the proportion of bovine embryos that developed to the expanded blastocyst stage (Song et al. 2009). Expression of genes involved in prostaglandin synthesis was reported by Dorniak et al. (2011). These authors concluded that PGF2 $\alpha$ and PGE2 are important regulators of conceptus elongation and mediators of endometrial responses to $\mathrm{P} 4$ in sheep. Therefore, because of critical effects of prostaglandins on embryo development during early dioestrus, deregulation of their biosynthesis may be one of the mechanisms associated with early embryonic loss in cattle.

Herein, we propose that prostanoids are a possible class of endocrine-modulated molecules that are important for embryo receptivity and thus female fertility at early dioestrus. In the present study, we are the first to evaluate the endocrine influences on prostanoid pathways in Day-7 endometrial tissue and uterine flushings; a timing that coincides with the moment of embryo reception by the maternal uterus. Therefore, we used a bovine fertility model as previously described by Mesquita et al. (2014, 2015), Ramos et al. (2014, 2015), Araújo et al. (2015) and França et al. (2015) and associated with fertility (Pugliesi et al. 2015) in order to evaluate whether peri-ovulatory variations in circulating steroids, positively associated with the ovulatory follicle size, regulate: (1) the expression of endometrial genes involved in the synthesis, transport, signalling and catabolism of eicosanoids and (2) the concentration of eicosanoids in endometrial tissue and uterine secretions.

\section{Materials and methods \\ Animal procedures}

This study was conducted at the Universidade de São Paulo, Pirassununga, São Paulo, Brazil. Animal procedures were approved by the Ethics and Animal Handling Committee of the School of Veterinary Medicine and Animal Science of the University of São Paulo with protocol number 2287/2011. Thirty multiparous Nelore cows (Bos taurus indicus) without reproductive abnormalities and with body-condition scores between 3 and 4 ( 0 being emaciate, 5 being obese) were kept on grazing conditions supplemented with sugarcane or corn silage (or both), concentrate and mineral salt. Animals received water ad libitum.

In order to form two groups of cows with different POF sizes and subsequent corpus luteum (CL) volume and P4 concentration, a hormonal protocol was used in all cows to manage endocrine patterns of the peri-ovulatory period as described by Mesquita et al. (2014). The model was based on the pharmacological control of follicle growth to result in a group exhibiting larger (LF-LCL group) or smaller (SF-SCL group) POF and CL and consequently resulting in different circulating $\mathrm{P} 4$ concentrations during early dioestrus. To reach this goal, cows $(n=15$ per group) received two intramuscular (i.m.) doses of prostaglandin F2 $\alpha$ (PGF; $0.5 \mathrm{mg}$; sodium cloprostenol; Sincrocio; Ourofino, Cravinhos, Brazil) 14 days apart. Following this pre-synchronisation procedure, ovaries were visualised using transrectal ultrasound scanning in order to confirm the presence of a PGF-responsible CL 10 days after the second PGF administration, (Day -10 of the experiment; D-10). On D-10, all cows were treated with $2 \mathrm{mg}$ of oestradiol benzoate (Sincrodiol; Ourofino) and received a P4 intravaginal releasing device (1 g; Sincrogest; Ourofino) to stimulate recruitment of a new follicular wave. Females assigned to the larger POF and subsequent larger CL group (LF-LCL) additionally received a PGF injection on D-10 (0.5 mg; sodium cloprostenol; Sincrocio; Ourofino) to induce CL regression during follicle development, whereas cows assigned to the smaller POF followed by smaller CL group (SF-SCL) did not. Sixty hours before the induction of ovulation, P4 devices were removed and a PGF dose $(0.5 \mathrm{mg}$; Cloprostenol) was administered i.m. to cows in the LF-LCL group, whereas cows in the SF-SCL group received the same treatment $12 \mathrm{~h}$ later (D-2.5 and D-2, respectively). Ovulation was induced on Day 0 by an i.m. administration of gonadotrophinreleasing hormone $(\mathrm{GnRH}$; $10 \mu \mathrm{g}$ buserelin acetate, Sincroforte; 
Ourofino). Seven days after induction of ovulation, cows that ovulated in response to GnRH within $48 \mathrm{~h}$ ( $n=11$ cows in the SF-SCL group and 12 cows in LF-LCL group) were slaughtered and their reproductive tracts were collected for further analysis. More details about the animal model are available in previous publications by our group (Mesquita et al. 2014; França et al. 2015).

\section{Ultrasonography}

The ovaries were evaluated by transrectal ultrasonography on D-10, D-6 and every $24 \mathrm{~h}$, starting on D-2 until D7, using both an Aloka SSD-500 attached to a 5-MHz linear probe (Hitachi Aloka, Tokyo, Japan) and an Esaote MyLab 30 attached to a multi-frequency probe (Esaote, Genoa, Italy) set between 6 and $7.5 \mathrm{MHz}$. Ultrasonography was performed to evaluate the presence and size of dominant follicles and CL. The maximum diameter and perpendicular diameter of the largest ovarian follicle were measured using a B-mode still image and an averaged diameter was calculated. Ovulation was defined as the disappearance of the largest ovarian follicle followed by the presence of a new CL at the same location. For evaluation of size of the CL, the maximum CL area was determined using a B-mode still image and the tracing function. For CL with an anechoic fluid-filled cavity, the area of the cavity was subtracted from the total area (Kastelic et al. 1990; Pugliesi et al. 2014).

\section{Sample collection and processing}

At D7 the animals were slaughtered for collection of the reproductive tract. The reproductive tissues were transported on ice to the laboratory within $15 \mathrm{~min}$. The uterine horn ipsilateral to the ovulation was flushed with $20 \mathrm{~mL}$ of phosphate-buffered saline (PBS). The uterine flushing was centrifuged at $3000 \mathrm{~g}$ for $30 \mathrm{~min}$ at $4^{\circ} \mathrm{C}$ and the supernatant was stored at $-80^{\circ} \mathrm{C}$ for quantification of eicosanoids. After the flushing, the ipsilateral uterine horn was dissected and fragments of the intercaruncular area were taken. This region was chosen because most endometrial glands responsible for secretion of histotroph are found in this region on the uterine tissue (Dhaliwal et al. 2002). The uterine samples were stored at $-80^{\circ} \mathrm{C}$ for quantification of RNA and prostanoid metabolites.

\section{Quantification of progesterone concentrations}

Blood samples were taken from the jugular vein on the day of slaughter (D7). Plasma was removed after blood centrifugation at $1500 \mathrm{~g}$ for $30 \mathrm{~min}$ at $4^{\circ} \mathrm{C}$. P4 plasma concentrations were measured in the samples using a commercial kit (Coat-A-Count; Siemens Medical Solutions Diagnostics, Los Angeles, CA, USA), previously validated for bovine plasma samples (Garbarino et al. 2004). The intra- and inter-assay $\mathrm{CV}$ and sensitivity for $\mathrm{P} 4$, were $0.3 \%, 7.0 \%$ and $0.076 \mathrm{ng} \mathrm{mL}^{-1}$, respectively.

\section{Transcript quantification by real-time reverse transcription} polymerase chain reaction (PCR)

Approximately $30 \mathrm{mg}$ of endometrial tissue was macerated in liquid nitrogen (SF-SCL, $n=11$; LF-LCL, $n=12$ ) and submitted to total RNA extraction using the RNeasy Mini columns kit (Qiagen Laboratories, Valência, CA, USA) according to the manufacturer's instructions. The RNA concentration was measured spectrophotometrically (NanoDrop; Thermo Scientific, Wilmington, MA, USA). Before the reverse transcription (RT), the RNA samples were treated with DNase I (deoxyribonuclease I, Pure Link Genomic DNA Purification; Invitrogen, Carlsbad, CA, USA) as per the manufacturer's instructions. Briefly, the treatment with DNase was done at room temperature using $1.0 \mu \mathrm{g}$ of RNA in a $10-\mu \mathrm{L}$ reaction volume. After $15 \mathrm{~min}$ of incubation, $1.0 \mu \mathrm{L}$ of ethylenediamine tetraacetic acid (EDTA, $25 \mathrm{mM}$; Invitrogen) was added and warmed to $65^{\circ} \mathrm{C}$ for $10 \mathrm{~min}$. Synthesis of cDNA was performed using a High-Capacity cDNA Reverse Transcription Kit (Life Technologies Corporation, Frederick, MD, USA). A master mix $(9.0 \mu \mathrm{L})$ was added to the $11.0 \mu \mathrm{L}$ of the treated samples. The samples were incubated at $25^{\circ} \mathrm{C}$ for $10 \mathrm{~min}$ and then at $37^{\circ} \mathrm{C}$ for $2 \mathrm{~h}$, followed by an enzymatic inactivation period at $85^{\circ} \mathrm{C}$ for $5 \mathrm{~min}$.

The primers were designed using the Oligo Analyzer 3.1 software (Integrated DNA Technologies, Inc., Coralville, IA, USA, http://www.idtdna.com/calc/analyzer, accessed 15 June 2012) and Software Primer Express 3.0.1 (Life Technologies, Frederick, MA, USA) or were obtained from previous reports. The qPCR reactions were performed using SYBR Green Chemistry for the amplification analysis in a thermocycler (Step One Plus Real Time System; Life Technologies, Frederick, MA, USA). The thermocycler was programmed to start in a holding stage $\left(95^{\circ} \mathrm{C}\right.$ for $\left.10 \mathrm{~min}\right)$, followed by 40 cycles. Each cycle had a denaturation step $\left(95^{\circ} \mathrm{C}\right.$ for $\left.15 \mathrm{~s}\right)$ and an annealing phase $\left(60^{\circ} \mathrm{C}\right.$ for $\left.1 \mathrm{~min}\right)$. A dissociation ('melting') curve was obtained immediately after the amplification and then maintained at $95^{\circ} \mathrm{C}$ for $15 \mathrm{~min}$, at $60^{\circ} \mathrm{C}$ for $1 \mathrm{~min}$ and then at $95^{\circ} \mathrm{C}$ for $15 \mathrm{~min}$. The criteria for validation of primers were: amplification efficiency between 85 and $110 \%$, absence of amplification of the negative control, a single peak in the melting curve and the smallest cycle threshold. Standard curves for each primer were validated using five progressive dilutions and using duplicates. This was obtained using a pool of endometrial cDNA samples in dilutions of $1: 20,1: 40,1: 80,1: 160$ and $1: 320\left(\mathrm{cDNA}: \mathrm{H}_{2} \mathrm{O}\right)$. Determination of PCR efficiency and $\mathrm{Cq}$ (quantification cycle) values per sample was performed with LinReg PCR software (http:// linregpcr.nl/, verified 28 August 2015). Quantification was obtained after normalisation of the target gene expression values (Cq values) by the endogenous control expression in triplicate values of peptidylprolyl isomerase A (cyclophilin A, PPIA), using the equation described by Pfaffl (2001) and expressed as a ratio of target gene-to-endogenous control. PCR products of reactions using the primers designed were submitted to electrophoresis and sequencing. Details of primers are provided in Table 1 and the validation data is given in Table S1, available as Supplementary Material to this paper.

\section{Quantification of prostanoid abundance}

Liquid chromatography - mass spectrometry ( $L C-M S / M S$ )

The prostanoid concentrations were measured in the endometrial tissue and in the uterine flushings from a subgroup of cows selected randomly from each experimental group $(n=4-6$ samples per group). The oxylipin analysis was basically performed as described by Lundström et al. (2013) using the 


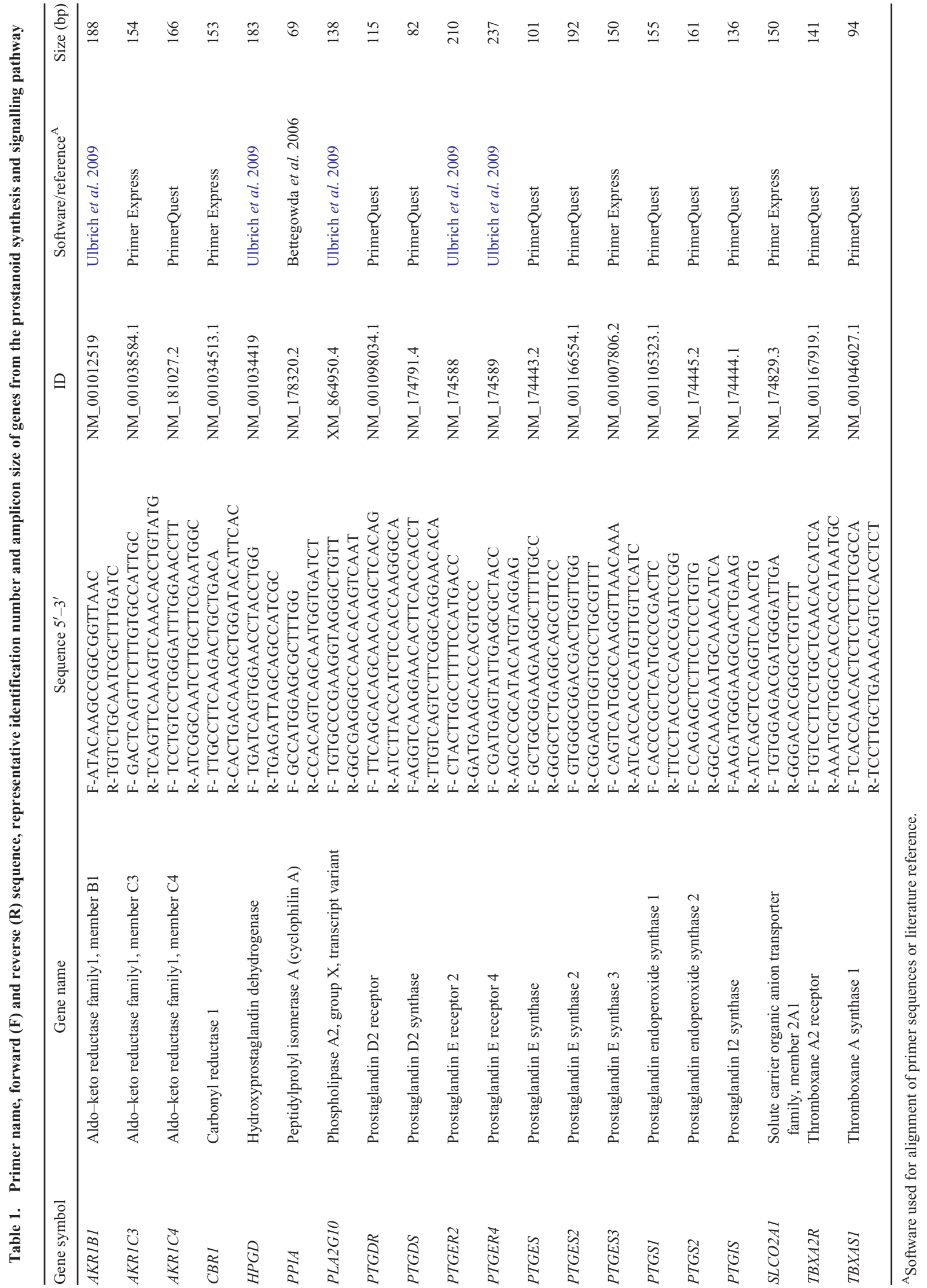


LC-MS/MS approach and is only briefly described here. The analytical standards and deuterated surrogates were obtained from Cayman Chemical (Ann Arbor, MI, USA), Larodan Fine Chemicals AB (Malmö, Sweden) or Biomol International (Plymouth Meeting, PA, USA). The oxylipins were extracted from $2 \mathrm{~mL}$ of uterine flushing using Waters Oasis-HBL cartridges (Waters, Milford, MA, USA) preconditioned with wash solution $\left(\mathrm{H}_{2} \mathrm{O}: \mathrm{MeOH} ; 95: 5\right.$, in $0.1 \%$ acetic acid). The uterine flushing aliquots, $200 \mu \mathrm{L}$ of wash solution, $10 \mu \mathrm{L}$ of surrogate standards ( $400 \mathrm{nM}$ per standard in $\mathrm{MeOH}), 10 \mu \mathrm{L}$ anti-oxidant and enzyme inhibitor solution $\left(0.2 \mathrm{mg} \mathrm{mL}^{-1}\right.$ of butylated hydroxytoluene (BHT), EDTA, thiamine pyrophosphate and indomethacin) were applied to the cartridge, rinsed with wash solution, eluted with $500 \mu \mathrm{L}$ of methanol and then with $1.5 \mathrm{~mL}$ of ethyl acetate and collected into polypropylene tubes containing $6 \mu \mathrm{L}$ of $30 \%$ glycerol in methanol. The solvent was stripped and the sample was suspended in $50 \mu \mathrm{L}$ of methanol containing the technical standard 1-cyclohexyl-dodecanoic acid urea (CUDA; $800 \mathrm{nM}$ ). The samples were then centrifuged at $10000 \mathrm{~g}$ for $30 \mathrm{~min}$ at $4^{\circ} \mathrm{C}$ and the supernatants were stored at $-20^{\circ} \mathrm{C}$ until analysis. Oxylipin profiling was performed using $10-\mu \mathrm{L}$ sample injections on a Waters ACQUITY UPLC system via a $2.1 \times 150 \mathrm{~mm}, 1.7-\mu \mathrm{m}$ Waters Acquity $\mathrm{BEH}$ column maintained at $60^{\circ} \mathrm{C}$ coupled to an XEVO TQ triple quadrupole mass spectrometer (Waters). The samples were maintained at $4^{\circ} \mathrm{C}$ before injection. Solvents A $(0.1 \%$ acetic acid in water $)$ and $\mathrm{B}$ (acetonitrile : methanol : acetic acid, $88: 12: 0.1$ ) were used in the following gradient: $15 \% \mathrm{~B}$ for $0.74 \mathrm{~min}, 30 \% \mathrm{~B}$ at $1.5 \mathrm{~min}$, $47 \% \mathrm{~B}$ at $3.5 \mathrm{~min}, 54 \% \mathrm{~B}$ at $6 \mathrm{~min}, 60 \% \mathrm{~B}$ at $10.5 \mathrm{~min}, 70 \% \mathrm{~B}$ at $15 \mathrm{~min}, 80 \% \mathrm{~B}$ at $16 \mathrm{~min}, 100 \% \mathrm{~B}$ from 17 to $19 \mathrm{~min}, 30 \% \mathrm{~B}$ from 19.3 to $21 \mathrm{~min}$. The oxylipins detected above the limit of quantitation (LOQ) were quantified, recalculated based on the original uterine flushing concentrations and normalised to the uterine flushing recovery (V[recovered volume]/V[instilled volume]). The normalisation to uterine flushing recovery did not affect the overall trends in the samples. For the endometrial tissue, the samples were previously extracted with organic solvents before solid-phase extraction. For this step, $100 \mathrm{mg}$ of cryo-pulverised endometrial tissue was added to amber vials ( $2 \mathrm{~mL}$, polytetrafluoroethylene (PTFE) caps; National Scientific Co., Rockwood, TN, USA) prepared with $5 \mu \mathrm{L}$ of BHT-EDTA $\left(0.2 \mathrm{mg} \mathrm{mL}^{-1}\right.$ in $\left.1: 1 \mathrm{MeOH}: \mathrm{H}_{2} \mathrm{O}\right)$ and $20 \mu \mathrm{L}$ of the surrogate standards $(1000 \mathrm{nM}$ per standard in $\mathrm{MeOH})$. Then, $500 \mu \mathrm{L}$ of $\mathrm{MeOH}$ was added and the vials were capped and then briefly vortexed. The samples were then centrifuged at $3.000 \mathrm{~g}$ and $0^{\circ} \mathrm{C}$ for $5 \mathrm{~min}$. The supernatant was collected and saved. Then, $350 \mu \mathrm{L}$ of isopropyl alcohol (IPA) was added to the remaining tissue. The samples were treated in an identical manner using methanol and the IPA extract was added to the $\mathrm{MeOH}$ fraction. The remaining tissue was mixed with $350 \mu \mathrm{L}$ of cyclohexane. The cyclohexane extract was treated as described above and the supernatant was pooled with IPA and $\mathrm{MeOH}$. The combined fraction was dried at reduced pressure (Genevac Inc., Stone Ridge, NY, USA) for $\sim 1 \mathrm{~h}$. The dried samples were reconstituted in $200 \mu \mathrm{L}$ of $\mathrm{MeOH}$ : toluene $(1: 1)$ and $100 \mu \mathrm{L}$ of a subaliquot of the extract was loaded into the solid phase extraction (SPE) cartridges and extracted as described above for the uterine flushing.

\section{Enzyme-linked immunosorbent assay (ELISA)}

Because a reduced number of samples was used for mass spectrometry and considering that PGE2 and PGF2 $\alpha$ are the most important prostanoids in the uterus, enzyme-linked immunosorbent assays (ELISAs) to measure the concentrations of PGE2 and PGF2 $\alpha$ in uterine flushing samples were validated using commercial kits for PGE2 and PGF $2 \alpha$ (both from Cayman Chemical Co.). Initially, a uterine flushing pool was treated with activated charcoal to remove prostaglandins (Turzillo and Fortune 1990). Briefly, $500 \mathrm{mg}$ of activated charcoal was added for each $\mathrm{mL}$ of uterine flushing and this mixture was incubated for $45 \mathrm{~min}$ and then centrifuged at $12000 \mathrm{~g}$ and $4^{\circ} \mathrm{C}$ for $1 \mathrm{~h}$. The supernatant was filtered and stored at $-80^{\circ} \mathrm{C}$. This prostaglandinfree matrix was used only to prepare PGE2 and PGF $2 \alpha$ standards from 15.6 to $1000 \mathrm{pg} \mathrm{mL}^{-1}$ and from 7.8 to $500 \mathrm{pg} \mathrm{mL}^{-1}$, respectively. The matrix volume added to each standard was equal at each standard-curve point (five points were used in each curve). The standard curves were compared with the curves produced using only the manufacturer's enzyme immunoassay (EIA) buffer and validated by parallelism. All of the assayspecific reagents were prepared as described and suggested by the manufacturers. After the plate setup and incubations, the absorptions were read spectrophotometrically at a wavelength of $414 \mathrm{~nm}$ (Labsystems Multiskan - MS; Thermo Fisher Scientific, Waltham, MA, USA). After validation, the concentrations of PGE2 and PGF2 $\alpha$ in the uterine flushings collected from a subset of cows in the LF-CL group $(n=10)$ and the SF-SCL group $(n=10)$ were assayed in duplicate. Concentrations were calculated in reference to a regression equation generated from a standard curve prepared with increasing concentrations of PGE2 or PGF $2 \alpha$, diluted in prostaglandin-free uterine flushing.

\section{Statistical analyses}

Outlying observations greater than two standard deviation ranges from the mean were not used in the statistical analyses. The data were tested for normality of the residues using the Shapiro-Wilk test and for homogeneity of variance using the F-max test and natural log-transformed if needed. The ovarian and endocrine variables were analysed by one-way ANOVA to test the effect of the treatment using the PROC GLM procedure of the SAS software (Version 9.2; SAS Institute, Cary, $\mathrm{NC}$, USA). The eicosanoid concentrations and relative gene expression levels were analysed through non-paired Students' $t$-test. Pearson's correlation coefficients were calculated between P4 concentrations, POF and CL size or P4 concentrations and abundance of transcripts and concentrations of prostanoids in the uterus, and between abundance of transcripts and concentrations of prostanoids in the endometrial tissues or uterine flushings. A probability of $\mathrm{P} \leq 0.05$ indicated that an effect was significant and a probability of $P>0.05$ to $\mathrm{P} \leq 0.1$ indicated that significance was approached.

\section{Results}

Ovarian responses and circulating P4 concentrations: animal model

The hormonal treatments successfully resulted in two groups of cows with distinct ovarian characteristics, as previously 
described by Mesquita et al. (2014). More specifically, cows assigned to the LF-LCL group had larger POF diameters when compared with animals from the SF-SCL group $(12.7 \pm 0.3 \mathrm{~mm}$ and $11.2 \pm 0.4 \mathrm{~mm}$, respectively; $P<0.05)$. Furthermore, the

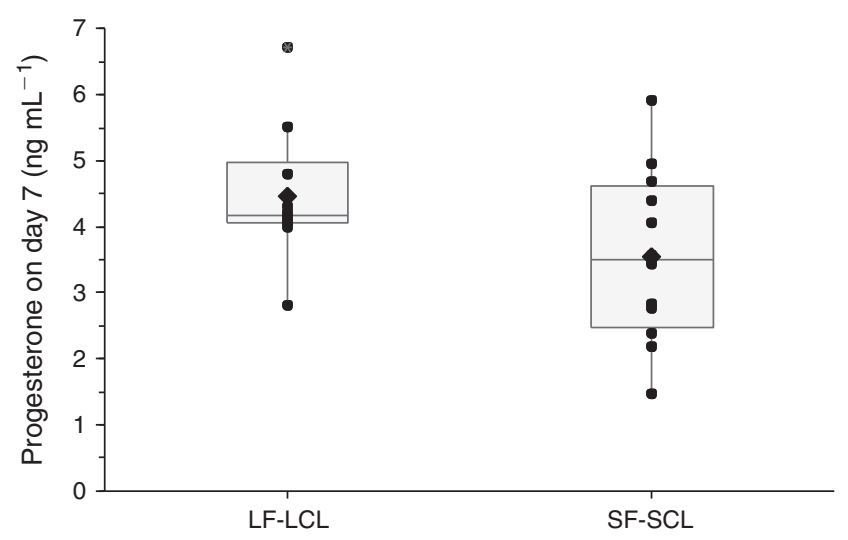

Fig. 1. Box plot showing the mean (diamond), median (continuous horizontal line) and individual values (dots) for progesterone concentrations (ng $\mathrm{mL}^{-1}$ ) on Day 7 after induction of ovulation in cows treated to achieve a large pre-ovulatory follicle and corpus luteum (LF-LCL group; $n=12$ ) and cows treated to achieve a small pre-ovulatory follicle and corpus luteum (SF-SCL group; $n=11$ ). larger POFs resulted in larger $\left(2.5 \pm 0.31 \mathrm{vs} 1.6 \pm 0.1 \mathrm{~cm}^{3}\right.$; $P<0.05)$ and heavier $(2.9 \pm 0.4$ vs $2.0 \pm 0.1 \mathrm{~g} ; P<0.05)$ corpora lutea on Day 7 after induction of ovulation. Mean P4 concentrations were higher in cows from the LF-LCL group when compared with cows from the SF-SCL group ( $4.4 \pm 0.4$ vs $3.5 \pm 0.3 \mathrm{ng} \mathrm{mL}^{-1} ; P<0.05$; Fig. 1).

\section{Transcript abundance in endometrial tissue}

Gene expression analyses showed that 5 out of 19 analysed genes displayed a significantly modulated expression in response to the differential peri-ovulatory endocrine profiles (Table 2; Fig. 2). More specifically, the expression of phospholipase A2 (PLA2G10), encoding an enzyme that releases arachidonic acid for eicosanoid synthesis, was decreased (fold change (fc) $0.58 ; P<0.05$ ) in the endometrium of cows belonging to the LF-LCL group when compared with the SF-SCL group. The abundance of prostaglandin E synthase (PTGES) transcripts in the LF-LCL group was higher than in the SF-SCL group (fc $1.32 ; P<0.05$ ). The latter prostaglandin synthase E2 enzyme converts prostaglandin $\mathrm{H} 2$ (PGH2) into PGE2. Furthermore, the gene expression levels of aldo-keto reductase family 1 , member $\mathrm{C} 4$ (AKR1C4) and aldo-keto reductase family 1 , member $\mathrm{C} 3$ ( $A K R 1 C 3)$, involved in PGF2 $\alpha$ synthesis, were upregulated (fc 1.65; $P<0.05$ and fc 1.84; $P<0.05$, respectively) in the LF-LCL group compared with the SF-SCL counterparts. Also the expression of prostaglandin

Table 2. Mean \pm s.e.m. of relative transcript abundance of target genes involved in prostanoid biosynthesis, signalling and catabolism in endometrial tissue at Day 7 after ovulation induction in cows with large pre-ovulatory follicle (POF) and large corpus luteum (LF-LCL, $n=11)$ and cows with small POF and small corpus luteum (SF-SCL, $n=10)$ NS, no significant difference

\begin{tabular}{|c|c|c|c|c|c|}
\hline Gene symbol & Gene name & LF-LCL & SF-SCL & $\begin{array}{c}\text { Fold change } \\
\text { LF-LCL/SF-SCL }\end{array}$ & $P$ value \\
\hline \multicolumn{6}{|c|}{ Prostanoid synthesis } \\
\hline PLA2G10 & Phospholipase A2, group X, transcript variant & $0.07 \pm 0.08$ & $0.12 \pm 0.01$ & 0.58 & 0.04 \\
\hline PTGS1 & Prostaglandin endoperoxide synthase 1 & $0.002 \pm 0.0003$ & $0.001 \pm 0.0001$ & 1.32 & NS \\
\hline$P T G S 2$ & Prostaglandin endoperoxide synthase 2 & $0.001 \pm 0.0002$ & $0.001 \pm 0.0003$ & 1.00 & NS \\
\hline PTGES & Prostaglandin E synthase & $0.004 \pm 0.0004$ & $0.003 \pm 0.0002$ & 1.32 & 0.05 \\
\hline PTGES2 & Prostaglandin E synthase 2 & $0.01 \pm 0.0006$ & $0.01 \pm 0.0005$ & 1.06 & NS \\
\hline PTGES3 & Prostaglandin E synthase 3 & $0.22 \pm 0.02$ & $0.2 \pm 0.03$ & 1.20 & NS \\
\hline$A K R 1 B 1$ & Aldo-keto reductase family 1 , member B1 & $0.34 \pm 0.02$ & $0.3 \pm 0.03$ & 1.09 & NS \\
\hline$A K R 1 C 4$ & Aldo-keto reductase family 1 , member $\mathrm{C} 4$ & $0.007 \pm 0.001$ & $0.004 \pm 0.0005$ & 1.65 & 0.04 \\
\hline$A K R 1 C 3$ & Aldo-keto reductase family 1 , member $\mathrm{C} 3$ & $0.004 \pm 0.0008$ & $0.002 \pm 0.0003$ & 1.84 & 0.02 \\
\hline$C B R 1$ & Carbonyl reductase 1 & $0.018 \pm 0.002$ & $0.01 \pm 0.002$ & 1.25 & 0.07 \\
\hline$P T G D S$ & Prostaglandin D2 synthase & $0.06 \pm 0.009$ & $0.06 \pm 0.006$ & 1.06 & NS \\
\hline PTGIS & Prostaglandin I2 synthase & $0.036 \pm 0.008$ & $0.029 \pm 0.007$ & 1.22 & 0.04 \\
\hline$T B X A S 1$ & Thromboxane A synthase 1 & $0.001 \pm 0.0002$ & $0.001 \pm 0.0002$ & 1.08 & NS \\
\hline \multicolumn{6}{|c|}{ Prostanoid transporter } \\
\hline SLCO2A1 & $\begin{array}{l}\text { Solute carrier organic anion transporter } \\
\text { family, member } 2 \mathrm{~A} 1\end{array}$ & $0.003 \pm 0.0007$ & $0.002 \pm 0.0005$ & 1.22 & NS \\
\hline \multicolumn{6}{|c|}{ Prostanoid receptors } \\
\hline PTGER2 & Prostaglandin E receptor 2 & $0.001 \pm 0.0001$ & $0.001 \pm 0.0001$ & 0.92 & NS \\
\hline PTGER4 & Prostaglandin E receptor 4 & $0.006 \pm 0.001$ & $0.006 \pm 0.0009$ & 1.09 & NS \\
\hline PTGDR & Prostaglandin D2 receptor & $0.0007 \pm 0.0001$ & $0.0006 \pm 0.0001$ & 1.03 & NS \\
\hline$T B X A 2 R$ & Thromboxane A2 receptor & $0.001 \pm 0.0001$ & $0.0004 \pm 0.0001$ & 3.39 & NS \\
\hline \multicolumn{6}{|c|}{ Prostanoid Catabolism } \\
\hline$H P G D$ & Hydroxyprostaglandin dehydrogenase & $0.17 \pm 0.017$ & $0.1441 \pm 0.0139$ & 1.20 & NS \\
\hline
\end{tabular}


I synthase (PTGIS), an enzyme that converts PGH2 into PGI2, was greater (fc $1.22 ; P<0.05$ ) in the endometrium from the LF-LCL group than in the SF-SCL group. The transcript abundance of carbonyl reductase $1(C B R 1)$, which uses PGE2 as a substrate for the synthesis of PGF $2 \alpha$, tended to be upregulated in the LF-LCL compared with the SF-SCL tissue (fc 1.25; $P=0.07)$. No difference $(P>0.1)$ between groups was detected for the transcripts of the main gene related to PGF $2 \alpha$ synthesis (aldo-keto reductase family 1, member B1 (AKR1B1); Fig. 2).

Eicosanoid abundance in endometrial tissue and in uterine flushings

LC-MS/MS data did not $(P>0.1)$ reveal significant changes in the concentrations of prostanoids between the LF-LCL and
SF-SCL endometrial tissue or uterine fluid (Tables 3 and 4). Moreover, concentrations of PGE2 and PGF2 $\alpha$ were also measured in a large number of samples ( $n=10$ cows per group) using ELISA techniques in the uterine flushing samples. Consistently, no differences $(P>0.1)$ in either PGE2 or PGF2 $\alpha$ concentrations were observed in the Day-7 uterine flushings when comparing LF-LCL versus SF-SCL treatments (Fig. 3).

\section{Correlations between P4 concentrations, POF and CL size}

Among the ovarian variables analysed, a significant positive correlation with the $\mathrm{P} 4$ concentrations was observed for CL diameter $(0.599 ; P=0.004), \mathrm{CL}$ area $(0.579 ; P=0.006), \mathrm{CL}$ volume $(0.554 ; P=0.009)$ and $\mathrm{CL}$ weight $(0.554 ; P=0.01)$. A tendency for positive correlation was also observed between

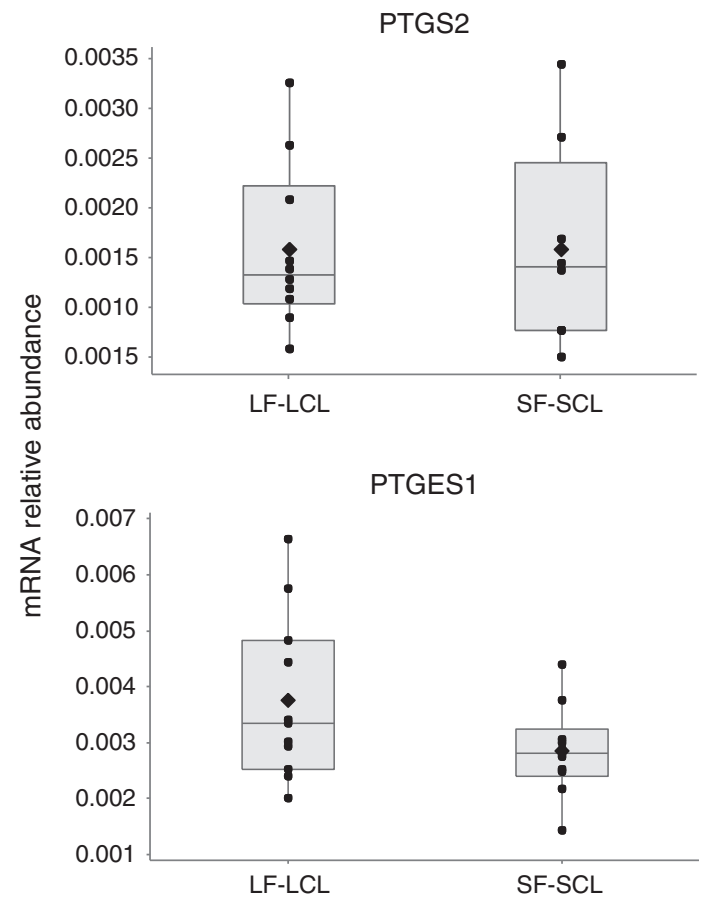

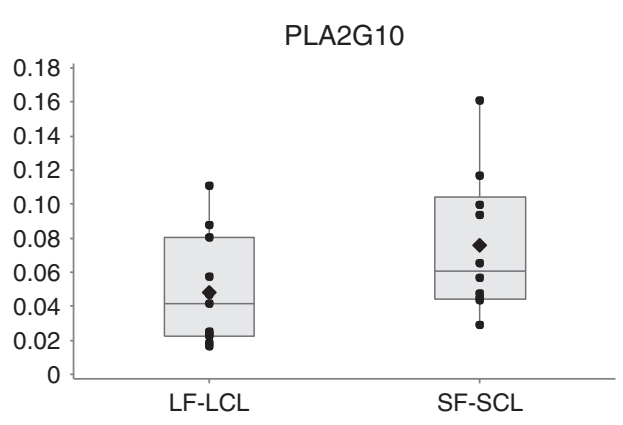

AKR1B1

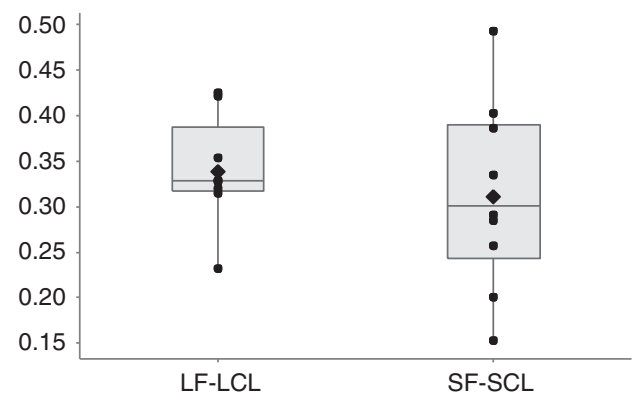

Fig. 2. Box plot showing the mean (diamond), median (continuous horizontal line) and individual values (dots) for relative abundance of mRNA for PTGS2, PLA2G10, PTGES1 and AKR1B1 on Day 7 after induction of ovulation in cows treated to achieve a large pre-ovulatory follicle and corpus luteum (LF-LCL group; $n=12$ ) and cows treated to achieve a small preovulatory follicle and corpus luteum (SF-SCL group; $n=11)$.

Table 3. Mean \pm s.e.m. of eicosanoid metabolite concentrations $\left(\mathrm{pg} \mathrm{mg}^{-1}\right)$ in the endometrial tissue at Day 7 after ovulation induction in cows with large pre-ovulatory follicle (POF) and large corpus luteum (LF-LCL, $n=4)$ and cows with small POF and small corpus luteum (SF-SCL, $n=5$ ) NS, no significant difference

\begin{tabular}{|c|c|c|c|c|}
\hline Eicosanoid metabolite $\left(\mathrm{pg} \mathrm{mg}^{-1}\right)$ & LF-FCL & SF-SCL & Fold change LF-LCL/SF-SCL & $P$ value \\
\hline Prostaglandin E2 & $9.72 \pm 2.51$ & $9.50 \pm 1.41$ & 1.02 & NS \\
\hline 8-Iso-prostaglandin E2 & $1.37 \pm 0.34$ & $1.15 \pm 0.58$ & 1.19 & NS \\
\hline 6-Keto-prostaglandin $1 \alpha$ & $53.0 \pm 1.1$ & $76.0 \pm 23.0$ & 0.70 & NS \\
\hline $11 \beta$-Prostaglandin F2 $\alpha$ & $1.14 \pm 0.44$ & $0.94 \pm 0.25$ & 1.21 & NS \\
\hline Prostaglandin D2 & $90.6 \pm 16.1$ & $86.9 \pm 18.3$ & 1.04 & NS \\
\hline$\Delta-12$ Prostanglandin $\mathrm{J} 2 /$ prostaglandin $\mathrm{J} 2$ & $0.08 \pm 0.01$ & $0.12 \pm 0.02$ & 0.72 & NS \\
\hline Thromboxane B2 & $0.56 \pm 0.12$ & $0.48 \pm 0.08$ & 1.16 & NS \\
\hline
\end{tabular}


Table 4. Mean \pm s.e.m. of concentrations $\left(\mathrm{pg} \mathrm{mL}^{-1}\right.$ ) of prostanoid metabolites in uterine flushings at Day 7 after ovulation induction in cows with large pre-ovulatory follicle (POF) and large corpus luteum (LF-LCL, $n=6)$ and cows with small POF and small corpus luteum $(\mathrm{SF}-\mathrm{SCL}, n=5)$ NS, no significant difference

\begin{tabular}{|c|c|c|c|c|}
\hline Prostanoid metabolite & LF-LCL & SF-SCL & Fold changeLF-LCL/SF-SCL & $P$ value \\
\hline Prostaglandin E2 & $115.2 \pm 28.0$ & $75.4 \pm 36.6$ & 1.53 & NS \\
\hline 8-Iso-prostaglandin E2 & $7.1 \pm 3.1$ & $3.8 \pm 0.3$ & 1.85 & NS \\
\hline Prostaglandin F2 $\alpha$ & $675.3 \pm 154.8$ & $664.4 \pm 249.4$ & 1.02 & NS \\
\hline Prostaglandin D2 & $53.1 \pm 14.9$ & $40.7 \pm 21.4$ & 1.31 & NS \\
\hline Prostaglandin $\mathrm{J} 2 / \Delta$ Prostaglandin $\mathrm{J} 2$ & $1.9 \pm 0.2$ & $1.9 \pm 0.2$ & 1.03 & NS \\
\hline 15-Deoxy- $\Delta-12.14$ prostaglandin J2 & $7.6 \pm 0.7$ & $8.4 \pm 0.8$ & 0.91 & NS \\
\hline 6-Keto-prostaglandin F1 $\alpha$ & $508.8 \pm 118.7$ & $507.4 \pm 164.5$ & 1.00 & NS \\
\hline Thromboxane B2 & $9.75 \pm 5.1$ & $18.1 \pm 8.8$ & 0.54 & NS \\
\hline
\end{tabular}

P4 concentrations on D7 and POF size $(0.414 ; P=0.062)$. Also, a positive correlation was detected between POF size and CL diameter $(0.613 ; P=0.002)$, area $(0.614 ; P=0.002)$, volume (0.612; $P=0.002)$ and weight $(0.697 ; P=0.001)$.

\section{Correlation between POF size and P4 concentrations} with the abundance of transcripts or concentrations of prostanoids in the uterus

There was no significant correlation between POF size and $\mathrm{P} 4$ concentrations and the abundance of transcripts for the enzymes involved in prostanoid synthesis, nor between POF size and $\mathrm{P} 4$ concentrations and concentrations of uterine metabolites analysed.

\section{Correlation between abundance of transcripts and concentrations of prostanoids in the endometrial tissues and uterine flushings}

There were significant correlations between abundance of transcripts and concentrations of prostanoids in the endometrial tissues and uterine flushings. The transcript for prostaglandin endoperoxide synthase 2 (PTGS2) was positively correlated with the concentrations of PGE2 $(0.865 ; P=0.0001)$ and PGF $2 \alpha(0.779 ; P=0.002)$ measured by ELISA. In contrast, the abundance of $P T G S 2$ was negatively correlated with the PGF2 $\alpha$ concentrations in the endometrial tissue $(-0.936 ; P=0.002)$ measured by MS/MS. In addition, no significant correlation was observed between prostaglandin synthase and its metabolites. The abundance of CBRI transcript, the gene encoding the enzyme responsible for PGE2 conversion to PGF2 $\alpha$, was positively correlated with PGF $2 \alpha$ concentrations in the uterine fluid (0.668; $P=0.005)$.

No difference $(P>0.1)$ in the ratio between PGF $2 \alpha$ and PGE2 (PGF2 $\alpha$ : PGE2) was detected between the LF-LCL (3.68) and SF-CL (4.97) groups.

\section{Discussion}

The quality of the preimplantation uterine environment encompasses a variety of aspects that potentially affect early embryo survival. Hormonal variations during each bovine oestrous cycle induce uterine changes that are crucial for its receptivity to the embryo, as indicated by the increased pregnancy rates in cows with higher circulating $\mathrm{P} 4$ concentrations at
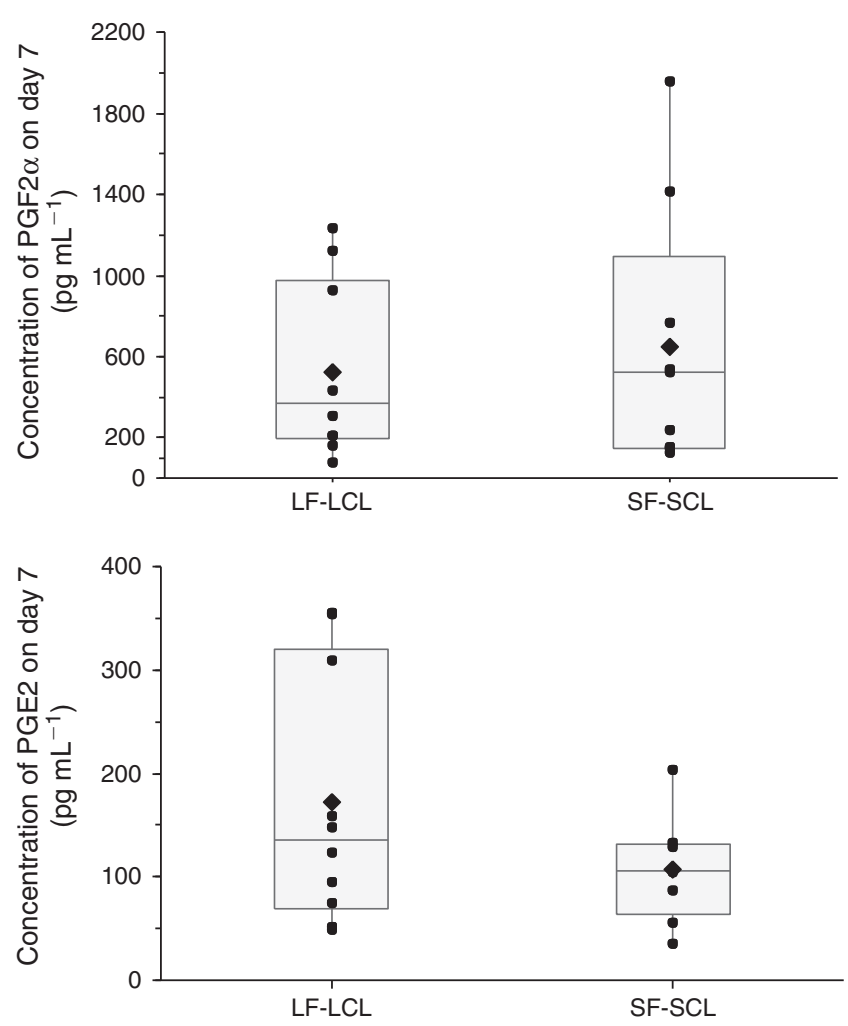

Fig. 3. Box plot showing the mean (diamond), median (continuous horizontal line) and individual values (dots) for PGF2 $\alpha$ and PGE2 concentrations (pg mL ${ }^{-1}$ ) in uterine flushings at Day 7 after induction of ovulation in cows treated to achieve a large pre-ovulatory follicle and corpus luteum (LF-LCL group; $n=10$ ) and cows treated to achieve a small pre-ovulatory follicle and corpus luteum (SF-SCL group; $n=10$ ).

Day 7 after insemination (McNeill et al. 2006; Peres et al. 2009). In the present study, we were the first to evaluate the endocrine influences on prostanoid pathways during early dioestrus, which coincides with the moment of embryo reception by the maternal uterus and may consequently interfere with embryo survival.

Considering that the POF size is positively associated with its capacity to secrete E2 and subsequent CL size and P4 secretion (Vasconcelos et al. 2001; Carter et al. 2008; Peres et al. 2009), we used an experimental model based on the modulation of 


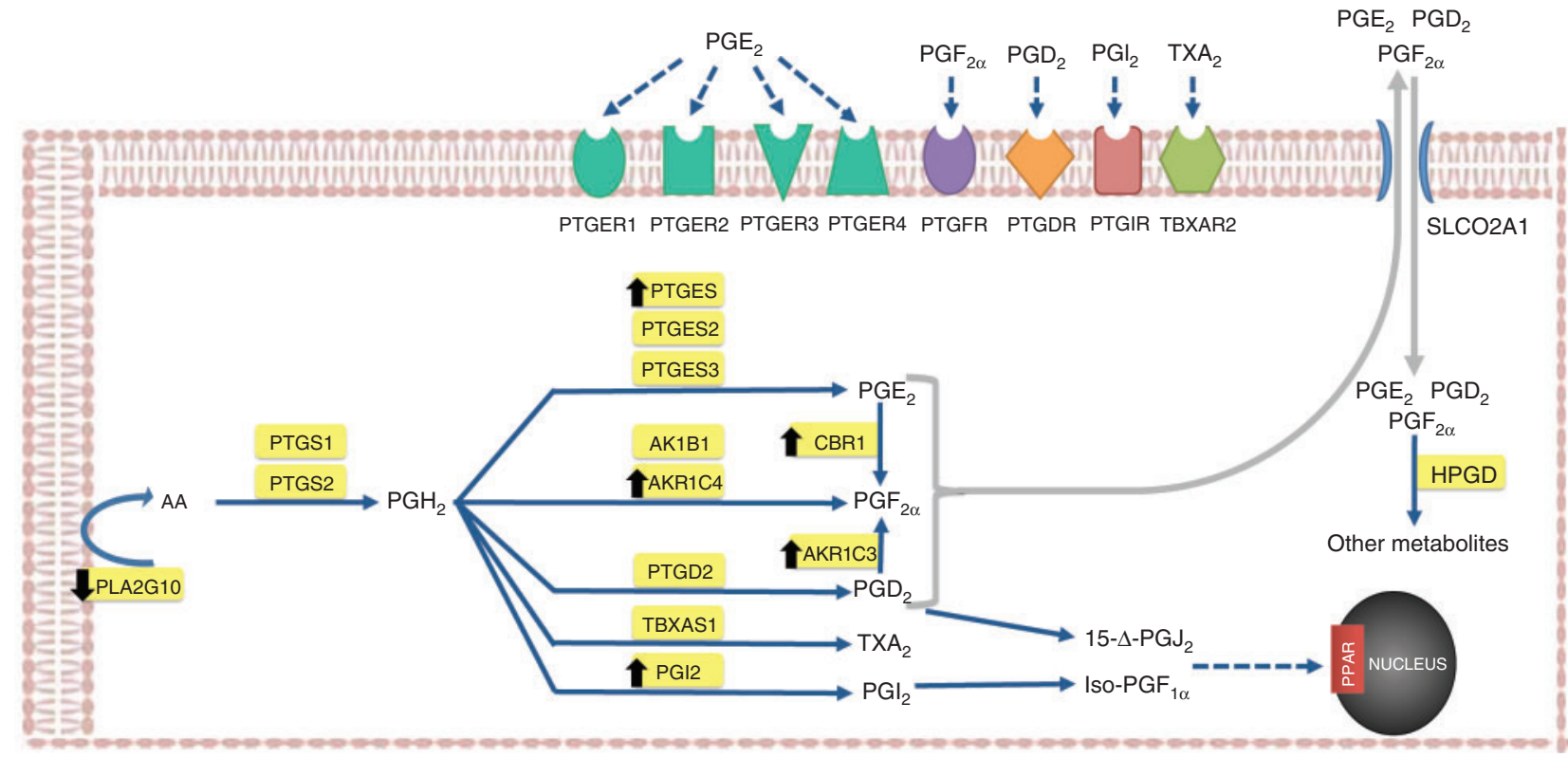

Fig. 4. Biosynthesis, metabolism and regulation pathways of prostanoids in the endometrium. The enzyme phospholipase A2 (PLA2) releases arachidonic acid (AA) from membrane phospholipids. The AA is metabolised by cyclo-oxygenases 1 and 2 (PTGS2 and PTGS1) to PGH2, which is the precursor of all prostanoids. Specific synthases convert PGH2 into PGE2 (PTGES1, PTGES2 and PTGES3), PGF2 $\alpha$ (AKR1B1, AKR1C3, AKR1C4 and CBR1), PGD2 (prostaglandin D2 synthase (PTGDS)), PGI2 (PTGIS) and TXA2 (thromboxane A synthase 1 (TBXAS1)). Once synthesised, the transport of prostaglandins through the plasma membrane is done bi-directionally, passively or facilitated by membrane carrier protein (solute carrier organic anion transporter family, member 2A1 (SLCO2A1)). Once outside the cell, prostaglandins can specifically bind to their membrane receptors PTGER1-4, PTGFR, PTGIR, prostaglandin D2 receptor (PTGDR) and thromboxane A2 receptor (TBXAR2). PGI2 and PGD2 promote their biological effects by signalling to nuclear receptors of the peroxisome proliferator-activated receptor (PPAR) family. Prostaglandins can be inactivated by the enzyme hydroxyprostaglandin dehydrogenase (HPDG), which converts prostaglandins to other metabolites. Up and down black arrows in the enzyme symbols indicate the up and downregulated genes, respectively, in the Day-7 endometrial tissue in cows that ovulated larger follicles and had larger corpus luteum (LF-LCL) compared with cows with smaller follicles and smaller corpus luteum. (Adapted from Fortier et al. 2008).

follicle growth and CL size, as has been previously described by our group (Mesquita et al. 2014, 2015; França et al. 2015; Ramos et al. 2014). In the present study, positive correlations between P4 concentrations on D7 and POF and CL size were observed. This confirmed that our experimental model not only modulated POF growth but efficiently altered CL growth and function, based on the $\mathrm{P} 4$ concentrations during early dioestrus. However, there was no significant correlation between POF size and $\mathrm{P} 4$ concentrations with the transcripts involved in the synthesis of PGE2 and PGF2 $\alpha$.

Based on the present results, at Day 7 after induction of ovulation the expression of several enzymes responsible for prostaglandin synthesis was upregulated in the endometrial tissue of cows that ovulated larger follicles compared with the tissue from cows ovulating small follicles and consequently small CLs. Using LC-MS/MS and ELISA techniques, the relevance of the differently expressed genes have been studied in detail, by eicosanoid identification and quantification in the Day-7 endometrial tissue and associated uterine flushings from cows ovulating large or small POF. Interestingly, no differences in concentrations of prostanoids could be observed either in endometrial tissue or in associated uterine flushings when comparing the experimental groups. In Fig. 4, an overview of the prostanoid metabolic pathway and the modulation of gene expression in the LF-LCL group is provided.
When focusing on the genes involved in each eicosanoid synthesis pathway, the endometrium of the cows in the LF-LCL group apparently supported synthesis of PGF $2 \alpha$. The expression of AKR1C3, AKR1C4, CBR1, PTGES and PTGIS was upregulated in cows with larger POF and CL. Indeed, expression of two enzymes belonging to the aldo-keto reductase family (AKR), which convert PGH2 into PGF2 $\alpha$ (Dozier et al. 2008; Bresson et al. 2011; Phillips et al. 2011), was stimulated in the LF-LCL endometrial tissue compared with the SF-SCL counterparts. This effect on expression of prostaglandin synthases may be caused by the combined effect of pre-ovulatory E2 and postovulatory P4 modulated by differential POF growth, as correlations between $\mathrm{P} 4$ concentrations alone and AKR enzymes and PTGES were not detected.

Despite the fact that abundance of mRNAs for $A K R I C 3$ and $A K R 1 C 4$ was upregulated in cows with larger POF and CL, the concentrations of PGF $2 \alpha$ were not increased in the endometrium and uterine flushings. Additional support for this mismatch was that a positive correlation between PGF $2 \alpha$ synthases and PGF $2 \alpha$ concentrations in uterine tissue and flushings were not detected. Several possible explanations should be taken into consideration. The first intuitive reason for this inconsistency is that the synthesis of PGF $2 \alpha$ is not dependent only on the conversion of PGH2 by the PGF synthases but also on the expression of other mediators, such as the cyclo-oxygenases (PTGS1 and PTGS2) 
to convert the arachidonic acid (AA) into PGH2. In this regard, the production of PGH2 by the cyclo-oxygenase PTGS1 (constitutive) and PTGS2 (regulatory) is considered the rate-limiting step of prostaglandin biosynthesis in the endometrium (Smith et al. 2000; Parent et al. 2003). This was supported in the present study by the strong positive correlations between PTGS2 and the concentrations of PGF2 $\alpha$ and PGE2 in the uterine flushings. Secretion of PGF $2 \alpha$ by endometrial explants is also correlated with their PTGS2 content, suggesting that the increase in the ability of the uterus to produce prostaglandin during the luteal phase of the oestrous cycle is due to the increase in PTGS2 levels (Charpigny et al. 1997). In addition, the expression of PTGS2 increases $70-100$ times before PGF $2 \alpha$ elevation at parturition, whereas PGF $2 \alpha$ synthase $(A K R 1 B 1)$ increases only 2.6 times (Schuler et al. 2006). Steroid hormones may modulate the expression of PTGS2 in endometrial cells (Madore et al. 2003), but the significant increase in P4 concentrations in cows with large POF and CL did not result in altered expression of this gene in the present study.

A second consideration is that the abundance of $A K R 1 B 1$ was also similar between cows with large and small POF and CL. AKR1B1 is considered to be the main synthase enzyme in the ARK family responsible for PGF $2 \alpha$ biosynthesis in the human and bovine endometrium (Madore et al. 2003; Bresson et al. 2011) and its expression is positively associated with PTGS2 abundance (Charpigny et al. 1997; Xiao et al. 1998; Schuler et al. 2006). Consequently, the similar abundance of transcripts for PTGS2 and AKR1B1 in cows with large or small POF and CL and the absence of a significant correlation between $\mathrm{P} 4$ concentrations and the abundance of these transcripts may be the main explanations for the lack of difference in PGF $2 \alpha$ concentrations in the endometrium and uterine flushings between groups. Therefore, the upregulation of $A K R 1 C 3$ and $A K R 1 C 4$ in cows with large POF and CL was possibly a response to the greater $\mathrm{P} 4$ concentrations on D7, as enzymes in the AKR family have a double function of prostaglandin synthesis and $\mathrm{P} 4$ catabolism (Pelletier et al. 1999; Madore et al. 2003; Ito et al. 2006). This result is also a novel finding, as a previous study reported that AKR1C family members were not expressed in the bovine endometrium during dioestrus (Madore et al. 2003).

Similarly, the concentrations of PGE2 were not increased in consequence of the greater abundance of PTGES1 transcript in cows with larger POF and CL. This mismatch between a synthase and its prostanoid may also be caused by the absence of the modulation of PTGS2 by the different peri-ovulatory endocrine profiles. In line with this, Arosh et al. (2002) suggested that the increased PGE2 production in endometrial cells is mainly caused by the associative upregulation of PTGES1 with PTGS2. In addition, lower levels of PGE synthase and PTGS2 in the bovine endometrium were detected between Days 1 and 12 of the oestrous cycle (Arosh et al. 2002), indicating a limited capacity of the uterus to secrete PGE2 during early and mid dioestrus. This also suggested that the cyclo-oxygenases might be the key component monitoring final prostaglandin concentrations in the bovine endometrium at early dioestrus. Furthermore, there was an increased abundance of $C B R 1$ transcripts in the LF-LCL group. This enzyme uses PGE2 as a substrate for the synthesis of PGF2 $\alpha$ (Kankofer and Wierciński
1999; Asselin and Fortier 2000; Kankofer et al. 2002). Therefore, part of the PGE2 converted by PTGES1 could be instantly transformed into PGF $2 \alpha$ by CBR1 activity. The concentrations of PGF $2 \alpha$ were greater than the concentrations of PGE2 in the uterine flushings and in the endometrial tissue on D7 of the oestrous cycle. Thus, at least part of this abundance of PGF $2 \alpha$ may be caused by the conversion of PGE2 into PGF $2 \alpha$ through $C B R 1$, as indicated by the positive correlation between PGF $2 \alpha$ and CBR1 in the uterine flushings.

A third consideration is related to the gene expression results of the PLA2G10 enzyme. This phospholipase comes into view as a potential regulator of eicosanoid homeostasis, as its downregulated expression in the LF-LCL compared with SF-SCL tissue might result in a limited substrate provision towards effective production of prostaglandins. In this regard, the PLA2 acts on the release of AA, the primary precursor of prostanoids (Godkin et al. 2008).

Another consideration regarding the mismatch between gene expression and prostaglandin concentrations is that our results are primarily based on the transcript abundance data. It is not clear whether all transcripts will be translated or even post-translationally modified (Robert 2010). A previous report (Ulbrich et al. 2009) documented a similar mismatch when comparing eicosanoid transcripts and metabolite concentrations in the uterus, although in a reverse way and during a later time window during dioestrus. Finally, post-transcriptional effects regulating activities should be considered as well. The importance of the latter assumption has been recently emphasised by Walker et al. (2013); DNA methylation is involved in early pregnancy events, which might point towards potential posttranscriptional alterations.

The complete role of prostaglandins in the fertility of cows still needs to be elucidated, but during early embryo development the evidence is that specific prostanoids are needed for adequate embryonic viability during early dioestrus. Previous research has revealed that development of bovine embryos is impaired by increased PGF2 $\alpha$ levels (Scenna et al. 2004, 2005) and is stimulated by PGE2 (Arosh et al. 2004; Ulbrich et al. 2009). Prostaglandins are also essential for elongation of the conceptus, as intrauterine infusions of a selective PTGS2 inhibitor prevented conceptus elongation in early-pregnant sheep (Simmons et al. 2010; Dorniak et al. 2011). In the present study, a bovine model was used in order to screen for endocrine preparation of maternal receptivity without the presence of the embryo. Considering the previous studies and our working model where cows with large POF and CL had an $80 \%$ increase in pregnancy rates (Pugliesi et al. 2015), the expectation was that cows in the LF-LCL group could stimulate PGE2 synthesis and inhibit PGF2 $\alpha$ in the endometrium. However, as the concentrations of PGE2 and PGF $2 \alpha$ were correlated only with abundance of transcripts for $P T G S 2$, the study of other important metabolic pathways in uterine tissue at early dioestrus are indicated to understand the positive effects of greater steroid concentrations during the peri-ovulatory period on bovine fertility.

In conclusion, the peri-ovulatory endocrine changes associated with the size of the POF regulate transcript abundance of genes belonging to prostanoid synthesis pathways in the bovine endometrium at early dioestrus (at Day 7 after induction 
of ovulation). Specifically, cows that ovulated larger follicles have increased abundance of AKR1C4, AKR1C3, PTGIS, $P T G E S$ and $C B R 1$ transcripts in the endometrium, whereas the expression of PLA2G10 was reduced. These changes in transcription do not result in modifications in the prostanoid concentrations in the endometrium nor in the uterine flushings, which probably result from the lack of modulation of PTGS2, the regulatory rate-limiting enzyme in prostaglandin biosynthesis. Indeed, the abundance of transcripts for PTGS2 is highly and positively correlated with PGF2 $\alpha$ and PGE2 concentrations in the uterine flushings. Although the concentrations of prostanoids are not affected by the peri-ovulatory endocrine profiles at this time point, these novel results characterising the prostanoid concentrations at early dioestrus point towards maintenance of homeostasis at the time of early embryo development.

\section{Acknowledgements}

This work was supported by LFEM (Projects \#: 204 and 206), CNPq (481199/2012-8) and FAPESP (2011/03226-4). The authors thank S. C. Scolari, R. Ramos, M. Sponchiado, M. França, Everton Lopes and Estela R. Araújo for technical assistance, the administration of the Pirassununga campus of the University of São Paulo and CAPES (Coordination for the Improvement of Higher Education Personnel), Brazil for a scholarship to the first author.

\section{References}

Araújo, E. R., Sponchiado, M., Pugliesi, G., Van Hoeck, V., Mesquita, F. S., Membrive, C. M., and Binelli, M. (2015). Spatio-specific regulation of endocrine-responsive gene transcription by peri-ovulatory endocrine profiles in the bovine reproductive tract. Reprod. Fertil. Dev. doi:10.1071/RD14178

Arosh, J. A., Parent, J., Chapdelaine, P., Sirois, J., and Fortier, M. A. (2002). Expression of cyclo-oxygenases 1 and 2 and prostaglandin E synthase in bovine endometrial tissue during the oestrous cycle. Biol. Reprod. 67, 161-169. doi:10.1095/BIOLREPROD67.1.161

Arosh, J. A., Banu, S. K., Chapdelaine, P., Madore, E., Sirois, J., and Fortier, M. A. (2004). Prostaglandin biosynthesis, transport and signalling in corpus luteum: a basis for autoregulation of luteal function. Endocrinology 145, 2551-2560. doi:10.1210/EN.2003-1607

Asselin, E., and Fortier, M. A. (2000). Detection and regulation of the messenger for a putative bovine endometrial 9-keto-prostaglandin $\mathrm{E}$ (2) reductase: effect of oxytocin and interferon-tau. Biol. Reprod. 62, 125-131. doi:10.1095/BIOLREPROD62.1.125

Bauersachs, S., Blum, H., Mallok, S., Wenigerkind, H., Rief, S., Prelle, K., and Wolf, E. (2003). Regulation of ipsilateral and contralateral bovine oviduct epithelial cell function in the postovulation period: a transcriptomics approach. Biol. Reprod. 68, 1170-1177. doi:10.1095/BIOLRE PROD.102.010660

Bauersachs, S., Ulbrich, S. E., Gross, K., Schmidt, S. E., Meyer, H. H., Wenigerkind, H., Vermehren, M., Sinowatz, F., Blum, H., and Wolf, E. (2006). Embryo-induced transcriptome changes in bovine endometrium reveal species-specific and common molecular markers of uterine receptivity. Reproduction 132, 319-331. doi:10.1530/REP.1.00996

Beltman, M. E., Forde, N., Furney, P., Carter, F., Roche, J. F., Lonergan, P., and Crowe, M. A. (2010). Characterization of endometrial gene expression and metabolic parameters in beef heifers yielding viable or non-viable embryos on D 7 after insemination. Reprod. Fertil. Dev. 22, 987-999. doi:10.1071/RD09302

Beltman, M. E., Mullen, M. P., Elia, G., Hilliard, M., Diskin, M. G., Evans, A. C., and Crowe, M. A. (2014). Global proteomic characterisation of uterine histotroph recovered from beef heifers yielding good-quality and degenerate Day-7 embryos. Domest. Anim. Endocrinol. 46, 49-57. doi:10.1016/J.DOMANIEND.2013.10.003

Binelli, M., Scolari, S. C., Pugliesi, G., Van Hoeck, V., Gonella-Diaza, A. M., Andrade, S. C., Gasparin, G. R., and Coutinho, L. L. (2015). The transcriptome signature of the receptive bovine uterus determined at early gestation. PLoS One 10, e0122874. doi:10.1371/JOURNAL. PONE.0122874

Bresson, E., Boucher-Kovalik, S., Chapdelaine, P., Madore, E., Harvey, N., Laberge, P. Y., Leboeuf, M., and Fortier, M. A. (2011). The human aldose reductase AKR1B1 qualifies as the primary prostaglandin $\mathrm{F}$ synthase in the endometrium. J. Clin. Endocrinol. Metab. 96, 210-219. doi:10.1210/JC.2010-1589

Bridges, G. A., Mussard, M. L., Pate, J. L., Ott, T. L., Hansen, T. R., and Day, M. L. (2012). Impact of pre-ovulatory oestradiol concentrations on conceptus development and uterine gene expression. Anim. Reprod. Sci. 133(1-2), 16-26. doi:10.1016/J.ANIREPROSCI.2012.06.013

Buford, W. I., Ahmad, N., Schrick, F. N., Butcher, R. L., Lewis, P. E., and Inskeep, E. K. (1996). Embryotoxicity of a regressing corpus luteum in beef cows supplemented with progestogen. Biol. Reprod. 54, 531-537. doi:10.1095/BIOLREPROD54.3.531

Carter, F., Forde, N., Duffy, P., Wade, M., Fair, T., Crowe, M. A., Evans, A. C., Kenny, D. A., Roche, J. F., and Lonergan, P. (2008). Effect of increasing progesterone concentration from Day 3 of pregnancy on subsequent embryo survival and development in beef heifers. Reprod. Fertil. Dev. 20, 368-375. doi:10.1071/RD07204

Charpigny, G., Reinaud, P., Tamby, J. P., Créminon, C., Martal, J., Maclouf, J., and Guillomot, M. (1997). Expression of cyclo-oxygenase-1 and -2 in ovine endometrium during the oestrous cycle and early pregnancy. Endocrinology 138, 2163-2171.

Cong, J., Diao, H. L., Zhao, Y. C., Ni, H., Yan, Y. Q., and Yang, Z. M. (2006). Differential expression and regulation of cyclo-oxygenases, prostaglandin E synthases and prostacyclin synthase in rat uterus during the peri-implantation period. Reproduction 131(1), 139-151. doi:10.1530/REP.1.00861

Dhaliwal, G. S., Murray, R. D., Rees, E. M., Howard, C. V., and Beech, D. J. (2002). Quantitative unbiased estimates of endometrial gland surface area and volume in cycling cows and heifers. Res. Vet. Sci. 73, 259-265. doi:10.1016/S0034-5288(02)00098-X

Diskin, M. G., and Morris, D. G. (2008). Embryonic and early fetal losses in cattle and other ruminants. Reprod. Domest. Anim. 43, 260-267. doi:10.1111/J.1439-0531.2008.01171.X

Diskin, M. G., and Sreenan, J. M. (1980). Fertilisation and embryonic mortality rates in beef heifers after artificial insemination. J. Reprod. Fertil. 59, 463-468. doi:10.1530/JRF.0.0590463

Diskin, M. G., Parr, M. H., and Morris, D. G. (2012). Embryo death in cattle: an update. Reprod. Fertil. Dev. 24, 244-251. doi:10.1071/RD11914

Dorniak, P., Bazer, F. W., and Spencer, T. E. (2011). Prostaglandins regulate conceptus elongation and mediate effects of interferon tau on the ovine uterine endometrium. Biol. Reprod. 84, 1119-1127. doi:10.1095/BIOL REPROD.110.089979

Dozier, B. L., Watanabe, K., and Duffy, D. M. (2008). Two pathways for prostaglandin $\mathrm{F} 2$ alpha synthesis by the primate peri-ovulatory follicle. Reproduction 136, 53-63. doi:10.1530/REP-07-0514

El-Sayed, A., Hoelker, M., Rings, F., Salilew, D., Jennen, D., Tholen, E., Sirard, M. A., Schellander, K., and Tesfaye, D. (2006). Large-scale transcriptional analysis of bovine embryo biopsies in relation to pregnancy success after transfer to recipients. Physiol. Genomics 28(1), 84-96. doi:10.1152/PHYSIOLGENOMICS.00111.2006

Forde, N., Carter, F., Fair, T., Crowe, M. A., Evans, A. C., Spencer, T. E., Bazer, F. W., McBride, R., Boland, M. P., O'Gaora, P., Lonergan, P., and Roche, J. F. (2009). Progesterone-regulated changes in endometrial gene expression contribute to advanced conceptus development in cattle. Biol. Reprod. 81, 784-794. doi:10.1095/BIOLREPROD.108.074336 
Fortier, M. A., Krishnaswamy, K., Danyod, G., Boucher-Kovalik, S., and Chapdalaine, P. (2008). A postgenomic integrated view of prostaglandins in reproduction: implications for other body systems. J. Physiol. Pharmacol. 59(Suppl 1), 65-89.

França, M. R., Mesquita, F. S., Lopes, E., Pugliesi, G., Van Hoeck, V., Chiaratti, M. R., Membrive, C. B., Papa, P. C., and Binelli, M. (2015). Modulation of peri-ovulatory endocrine profiles in beef cows: consequences for endometrial glucose transporters and uterine fluid glucose levels. Domest. Anim. Endocrinol. 50, 83-90. doi:10.1016/J.DOMA NIEND.2014.09.005

Garbarino, E. J., Hernandez, J. A., Shearer, J. K., Risco, C. A., and Thatcher, W. W. (2004). Effect of lameness on ovarian activity in postpartum hostein cows. J. Dairy Sci. 87, 4123-4131. doi:10.3168/jds.S0022-0302 (04)73555-9

Godkin, J. D., Roberts, M. P., Elgayyar, M., Guan, W., and Tithof, P. K. (2008). Phospholipase A2 regulation of bovine endometrial (BEND) cell prostaglandin production. Reprod. Biol. Endocrinol. 6, 44. doi:10.1186/ 1477-7827-6-44

Hockett, M. E., Rohrbach, N. R., and Schrick, F. N. (2004). Alterations in embryo development in progestogen-supplemented cows administered prostaglandin F2alpha. Prostaglandins Other Lipid Mediat. 73, 227-236. doi:10.1016/J.PROSTAGLANDINS.2004.02.002

Ito, K., Utsunomiya, H., Suzuki, T., Saitou, S., Akahira, J., Okamura, K., Yaegashi, N., and Sasano, H. (2006). 17Beta-hydroxysteroid dehydrogenases in human endometrium and its disorders. Mol. Cell. Endocrinol. 248, 136-140. doi:10.1016/J.MCE.2005.11.038

Kankofer, M., and Wierciński, J. (1999). Prostaglandin E2 9-keto reductase from bovine term placenta. Prostaglandins Leukot. Essent. Fatty Acids 61(1), 29-32. doi:10.1054/PLEF.1999.0069

Kankofer, M., Wierciński, J., and Zerbe, H. (2002). Prostaglandin E(2) 9-keto reductase activity in bovine retained and not-retained placenta. Prostaglandins Leukot. Essent. Fatty Acids 66, 413-417. doi:10.1054/ PLEF.2002.0367

Kastelic, J. P., Pierson, R. A., and Ginther, O. J. (1990). Ultrasonic morphology of corpora lutea and central luteal cavities during the estrous cycle and early pregnancy in heifers. Theriogenology 34, 487-498. doi:10.1016/0093-691X(90)90006-F

Lim, H., Paria, B. C., Das, S. K., Dinchuk, J. E., Langenbach, R., Trzaskos, J. M., and Dey, S. K. (1997). Multiple female reproductive failures in cyclo-oxygenase 2-deficient mice. Cell 91, 197-208. doi:10.1016/ S0092-8674(00)80402-X

Lundström, S. L., Saluja, R., Adner, M., Haeggström, J. Z., Nilsson, G., and Wheelock, C. E. (2013). Lipid mediator metabolic profiling demonstrates differences in eicosanoid patterns in two phenotypically distinct mast cell populations. J. Lipid Res. 54, 116-126. doi:10.1194/JLR. M030171

Madore, E., Harvey, N., Parent, J., Chapdelaine, P., Arosh, J. A., and Fortier, M. A. (2003). An aldose reductase with 20 alpha-hydroxysteroid dehydrogenase activity is most likely the enzyme responsible for the production of prostaglandin F2 alpha in the bovine endometrium. J. Biol. Chem. 278, 11205-11212. doi:10.1074/JBC.M208318200

Mansouri-Attia, N., Aubert, J., Reinaud, P., Giraud-Delville, C., Taghouti, G., Galio, L., Everts, R. E., Degrelle, S., Richard, C., Hue, I., Yang, X., Tian, X. C., Lewin, H. A., Renard, J. P., and Sandra, O. (2009). Gene expression profiles of bovine caruncular and intercaruncular endometrium at implantation Physiol. Genomics 39, 14-27. doi:10.1152/PHYSIOLGE NOMICS.90404.2008

McNeill, R. E., Diskin, M. G., Sreenan, J. M., and Morris, D. G. (2006). Associations between milk progesterone concentration on different days and with embryo survival during the early luteal phase in dairy cows. Theriogenology 65, 1435-1441. doi:10.1016/J.THERIOGENOLOGY. 2005.08.015
Mesquita, F. S., Pugliesi, G., Scolari, S. C., França, M. R., Ramos, R. S., Oliveira, M., Papa, P. C., Bressan, F. F., Meirelles, F. V., Silva, L. A., Nogueira, G. P., Membrive, C. M., and Binelli, M. (2014). Manipulation of the peri-ovulatory sex steroidal milieu affects endometrial but not luteal gene expression in early dioestrus Nelore cows. Theriogenology 81, 861-869. doi:10.1016/J.THERIOGENOLOGY.2013.12.022

Mesquita, F. S., Ramos, R. S., Pugliesi, G., Andrade, S. C., Van Hoeck, V., Langbeen, A., Oliveira, M. L., Gonella-Diaza, A. M., Gasparin, G., Fukumasu, H., Pulz, L. H., Membrive, C. M., Coutinho, L. L., and Binelli, M. (2015). The receptive endometrial transcriptomic signature indicates an earlier shift from proliferation to metabolism at early dioestrus in the cow. Biol. Reprod. doi:10.1095/BIOLREPROD.115.129031

Mosher, A. A., Rainey, K. J., Giembycz, M. A., Wood, S., and Slater, D. M. (2012). Prostaglandin E2 represses interleukin 1 beta-induced inflammatory mediator output from pregnant human myometrial cells through the EP2 and EP4 receptors. Biol. Reprod. 87(1), 7. doi:10.1095/BIOL REPROD.112.100099

Parent, J., Villeneuve, C., and Fortier, M. A. (2003). Evaluation of the contribution of cyclo-oxygenase 1 and cyclo-oxygenase 2 to the production of PGE2 and PGF2 alpha in epithelial cells from bovine endometrium. Reproduction 126, 539-547. doi:10.1530/REP.0.1260539

Pelletier, G., Luu-The, V., Têtu, B., and Labrie, F. (1999). Immunocytochemical localisation of Type 5 17beta-hydroxysteroid dehydrogenase in human reproductive tissues. J. Histochem. Cytochem. 47, 731-737. doi: $10.1177 / 002215549904700602$

Peres, R. F., Claro, I., Sá Filho, O. G., Nogueira, G. P., and Vasconcelos, J. L. (2009). Strategies to improve fertility in Bos indicus post-pubertal heifers and non-lactating cows submitted to fixed-time artificial insemination. Theriogenology 72, 681-689. doi:10.1016/J.THERIOGENOLOGY. 2009.04 .026

Pfaffl, M. W. (2001). A new mathematical model for relative quantification in real-time RT-PCR. Nucleic Acids Res. 29, e45. doi:10.1093/NAR/29. 9.E45

Phillips, R. J., Al-Zamil, H., Hunt, L. P., Fortier, M. A., and López Bernal, A. (2011). Genes for prostaglandin synthesis, transport and inactivation are differentially expressed in human uterine tissues and the prostaglandin F synthase AKR1B1 is induced in myometrial cells by inflammatory cytokines. Mol. Hum. Reprod. 17, 1-13. doi:10.1093/MOLEHR/GAQ057

Pohler, K. G., Geary, T. W., Atkins, J. A., Perry, G. A., Jinks, E. M., and Smith, M. F. (2012). Follicular determinants of pregnancy establishment and maintenance. Cell Tissue Res. 349, 649-664. doi:10.1007/S00441012-1386-8

Pugliesi, G., Miagawa, B. T., Paiva, Y. N., França, M. R., Silva, L. A., and Binelli, M. (2014). Conceptus-induced changes in the gene expression of blood immune cells and the ultrasound-accessed luteal function in beef cattle: how early can we detect pregnancy? Biol. Reprod. 91, 95. doi:10.1095/BIOLREPROD.114.121525

Pugliesi, G., Santos, F. B., Lopes, E., Nogueira, É., Maio, J. R. G., and Binelli, M. (2015). Fertility response in suckled beef cows supplemented with long-acting progesterone after timed artificial insemination. Reprod. Fertil. Dev. 27, 98. doi:10.1071/RDV27N1AB11

Ramos, R. S., Mesquita, F. S., D’Alexandri, F. L., Gonella-Diaza, A. M., Papa Pe, C., and Binelli, M. (2014). Regulation of the polyamine metabolic pathway in the endometrium of cows during early dioestrus. Mol. Reprod. Dev. 81, 584-594. doi:10.1002/MRD.22323

Ramos, R. S., Oliveira, M. L., Izaguirry, A. P., Vargas, L. M., Soares, M. B., Mesquita, F. S., Santos, F. W., and Binelli, M. (2015). The peri-ovulatory endocrine milieu affects the uterine redox environment in beef cows. Reprod. Biol. Endocrinol. 13, 39. doi:10.1186/S12958-015-0036-X

Robert, C. (2010). Microarray analysis of gene expression during early development: a cautionary overview. Reproduction 140, 787-801. doi:10.1530/REP-10-0191 
Scenna, F. N., Edwards, J. L., Rohrbach, N. R., Hockett, M. E., Saxton, A. M., and Schrick, F. N. (2004). Detrimental effects of prostaglandin F2alpha on preimplantation bovine embryos. Prostaglandins Other Lipid Mediat. 73, 215-226. doi:10.1016/J.PROSTAGLANDINS.2004.02.001

Scenna, F. N., Hockett, M. E., Towns, T. M., Saxton, A. M., Rohrbach, N. R., Wehrman, M. E., and Schrick, F. N. (2005). Influence of a prostaglandin synthesis inhibitor administered at embryo transfer on pregnancy rates of recipient cows. Prostaglandins Other Lipid Mediat. 78, 38-45. doi:10.1016/J.PROSTAGLANDINS.2005.02.003

Schrick, F. N., Inskeep, E. K., and Butcher, R. L. (1993). Pregnancy rates for embryos transferred from early postpartum beef cows into recipients with normal oestrous cycles. Biol. Reprod. 49, 617-621. doi:10.1095/ BIOLREPROD49.3.617

Schuler, G., Teichmann, U., Kowalewski, M. P., Hoffmann, B., Madore, E., Fortier, M. A., and Klisch, K. (2006). Expression of cyclo-oxygenase-II (COX-II) and 20alpha-hydroxysteroid dehydrogenase (20alpha-HSD)/ prostaglandin F-synthase (PGFS) in bovine placentomes: implications for the initiation of parturition in cattle. Placenta 27, 1022-1029. doi:10.1016/J.PLACENTA.2005.11.001

Seals, R. C., Lemaster, J. W., Hopkins, F. M., and Schrick, F. N. (1998) Effects of elevated concentrations of prostaglandin F2 alpha on pregnancy rates in progestogen-supplemented cattle. Prostaglandins Other Lipid Mediat. 56, 377-389. doi:10.1016/S0090-6980(98)00063-X

Simmons, R. M., Satterfield, M. C., Welsh, T. H., Bazer, F. W., and Spencer, T. E. (2010). HSD11B1, HSD11B2, PTGS2 and NR3C1 expression in the peri-implantation ovine uterus: effects of pregnancy, progesterone and interferon tau. Biol. Reprod. 82, 35-43. doi:10.1095/BIOLRE PROD.109.079608

Smith, W. L., DeWitt, D. L., and Garavito, R. M. (2000). Cyclo-oxygenases: structural, cellular and molecular biology. Annu. Rev. Biochem. 69, 145-182. doi:10.1146/ANNUREV.BIOCHEM.69.1.145

Song, B. S., Kim, J. S., Kim, C. H., Han, Y. M., Lee, D. S., Lee, K. K., and Koo, D. B. (2009). Prostacyclin stimulates embryonic development via regulation of the cAMP response element-binding protein-cyclooxygenase-2 signalling pathway in cattle. Reprod. Fertil. Dev. 21, 400-407. doi:10.1071/RD08180

Turzillo, A. M., and Fortune, J. E. (1990). Suppression of the secondary FSH surge with bovine follicular fluid is associated with delayed ovarian follicular development in heifers. J. Reprod. Fertil. 89, 643-653. doi:10.1530/JRF.0.0890643

Ulbrich, S. E., Schulke, K., Groebner, A. E., Reichenbach, H. D., Angioni, C. Geisslinger, G., and Meyer, H. H. (2009). Quantitative characterisation of prostaglandins in the uterus of early pregnant cattle. Reproduction 138, 371-382. doi:10.1530/REP-09-0081

Ulbrich, S. E., Wolf, E., and Bauersachs, S. (2013). Hosting the preimplantation embryo: potentials and limitations of different approaches for analysing embryo-endometrium interactions in cattle. Reprod. Fertil. Dev. 25, 62-70. doi:10.1071/RD12279

Vasconcelos, J. L., Sartori, R., Oliveira, H. N., Guenther, J. G., and Wiltbank, M. C. (2001). Reduction in size of the ovulatory follicle reduces subsequent luteal size and pregnancy rate. Theriogenology 56, 307-314. doi:10.1016/S0093-691X(01)00565-9

Vilella, F., Ramirez, L., Berlanga, O., Martínez, S., Alamá, P., Meseguer, M., Pellicer, A., and Simón, C. (2013). PGE2 and PGF2 $\alpha$ concentrations in human endometrial fluid as biomarkers for embryonic implantation. J. Clin. Endocrinol. Metab. 98, 4123-4132. doi:10.1210/JC.2013-2205

Walker, C. G., Littlejohn, M. D., Mitchell, M. D., Roche, J. R., and Meier, S (2012). Endometrial gene expression during early pregnancy differs between fertile and subfertile dairy cow strains. Physiol. Genomics 44, 47-58. doi:10.1152/PHYSIOLGENOMICS.00254.2010

Walker, C. G., Littlejohn, M. D., Meier, S., Roche, J. R., and Mitchell, M. D. (2013). DNA methylation is correlated with gene expression during early pregnancy in Bos taurus. Physiol. Genomics 45, 276-286. doi:10.1152/PHYSIOLGENOMICS.00145.2012

Weems, C. W., Weems, Y. S., and Randel, R. D. (2006). Prostaglandins and reproduction in female farm animals. Vet. J. 171, 206-228. doi:10.1016 J.TVJL.2004.11.014

Wiltbank, M. C., and Ottobre, J. S. (2003). Regulation of intraluteal production of prostaglandins. Reprod. Biol. Endocrinol. 1, 91. doi:10.1186/ 1477-7827-1-91

Xiao, C. W., Liu, J. M., Sirois, J., and Goff, A. K. (1998). Regulation of cyclo-oxygenase-2 and prostaglandin $\mathrm{F}$ synthase gene expression by steroid hormones and interferon-tau in bovine endometrial cells. Endocrinology 139, 2293-2299. 